\title{
自然言語によるヒューマノイドロボットの行動操作システム
}

\author{
$\bigcirc \mathrm{NEO}$ Ee Sian(産総研) 阪口健 (産総研) 横井一仁 (産総研)
}

\section{A Humanoid Robot Behavioral Operation System Using Natural Language}

\author{
*Ee Sian NEO(JRL, AIST), Takeshi SAKAGUCHI (JRL, AIST), \\ Kazuhito YOKOI (JRL, AIST)
}

\begin{abstract}
This paper explains the construction of a behavior level operation system which enables an operator to operate humanoid robots by using natural language instructions. We report on a system using a speech recognition module built on an embedded system and the implementation of the system using RT middleware on HRP-2.
\end{abstract}

Key Words: Humanoid Robot, Natural Language, Behavioral Operation

\section{1.はじめに}

次世代のロボットには，工場での作業のみならず，人 間の生活環境であるオフィスや家庭で多種なサービス を提供する㐫用が考えられる. 人間とコミュニケーショ ンをしながらサービスを提供するシステムにおいては, 人間にとって自然なマンマシンインタフェースとして、 自然言語による音声対話機能が重要な役割を演ずる。

ロボットとの自然言語インタフェースの研究は，人 工知能の分野で古くから研究されてきた題材であり, 1960 年代の移動ロボットSHAKEYの研究 [1] にまで 遡る。近年では、実世界で動くロボットの対話システ ム [3][2][7][5] の他に、CG アニメーテッドェージェン トのための自然言語インタフェースの研究も盛んに行 われるようになってきた [4][6]。

我々は自然言語を用いて柔軟にヒューマノイドロボッ トを操作できるシステムの実現を目指している。1

\section{2. 音声認識システム}

ヒューマノイドロボットは、駆動系、情報処理系、バッ テリ等、ロボットを構成する全ての部品を体内に詰め 込まなければならず、体内に搭載できる CPUの数や性 能も限られている。このため、従来ヒューマノイドロ ボットでは、その高品質な実時間伝送が情報量の多さ から難しい画像認識処理は体内の計算機で行っている のに対し、比較的情報量の少ない音声認識処理は、ロ ボットが計測した音声データを外部の計算機に伝送し て処理していた。これに対し、本研究開発では、独立行 政法人新エネルギー・産業技術総合開発機構 (NEDO) の「次世代ロボット共通基盤開発プロジェクト／音声 認識用デバイス及びモジュールの開発」で研究開発し た音声認識モジュール [8] をロボットに搭載することに より、無線 LAN などの通信インフラが無い状況でも、 音声認識と画像認識を同時に行うことができるように なることが期待される。

平成 17 年度には、市販の8チャンネル音声入力ボー ドをヒューマノイドロボットHRP-2に搭載し、脚部動 作中、腕部動作中、頭部動作中、発話中それぞれにおい

\footnotetext{
1 本研究の一部は、NEDO「次世代ロボット共通基盤荓発プロジェ クト」の委託において尖施された。
}

て、人が話しかけた場合の音声データを収集し、ロボッ 卜の発話やメカノイズが音声認識に与える影響を検討 し、平成 18 年度には、ヒューマノイドロボット HRP-2 の制御システムから、RT コンポーネントである音声 認識モジュ一ルにアクセスするソフトウェアの開発な らびにヒューマノイドロボット HRP-2に開発された音 声認識モジュールを組み込むためにヒューマノイドロ ボットHRP-2 の頭部を改造した。平成 19 年度には、 ヒューマノイドロボット HRP-2 に開発された音声認識 モジュールを組み込み、オフィス、公共施設、家庭等の 日常生活空間模擬環境において不特定話者により音声 指示された特定の行動を行わせる実証試験を行い、提 案音声認識システムの有効性の評洒を行う。

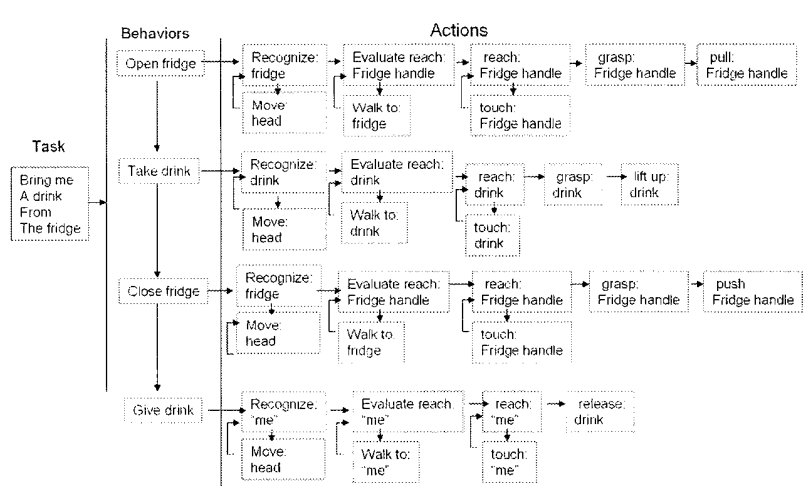

Fig. 1 The Task of Taking a Drink From the Fridge

\section{3. 行動辞書の作成}

自然言語を用いて柔軟にヒューマノイドロボットを 操作できるシステムを実現するためには、多種多様な タスク (Task) に共通に必要される行動 (Behavior) お よび行為 (Action) の辞書を構築する必要がある。

ここでは、行為をタスクを遂行するためのもっとも 基本的な動作単位とし、行動を行為をいくつか組み合 わせたものであると定義する。ユーザーから行為の命 令が指示された場合は、行為を実行する。行動の命令 が指示された場合は、行為辞書を用いて行為の組合せ 
を計画して行動を実現し、タスクを遂行する。

例えば「冷蔵庫から飲物をとってきて」という夕ス ク命令が指示された場合を考えてみる。Fig.1 に示す ように、このタスクを「冷蔵庫を開ける」、「飲物を取 る」、「冷蔵庫をしめる」、「飲物を渡す」の4つの行動 に分解し、さらに「冷蔵庫を開ける」という行動はま た「冷蔵庫を探す」、冷蔵庫までの距離に基づて歩く 必要があるかどうかを判断し、必要があれば「冷蔵庫 まで歩く」、必要がなけ㞦ば「冷蔵庫のハンドルに手で リーチする」、「ハンドルを握る」、「ハンドルを引っ張 る」といった行為に分解できると考えられる。

本研究の目的は日常生活環境で人間の支援を行うた めに多種多様な夕スクに共通に必要とされる行動・行 為のデータベースの構築である。

我々の行為辞書構築は以下の分類で行う：

- 知覚行為 (Perceptive Act):

環境認識や環境とのインタラクションの中で行う 視覚・聴覚・触覚によるセンシンプロセスや認識 プロセス.

例:冷蔵庫を目で認識する、ハンドルとの接触を力 センサで知覚する等

- 身体動作 (Body Action):

- 対象物の伴う動作:

例:午を取る、ハンドルを押す

- 対象物の伴わない動作:

例:歩く、しゃがむ

\section{4. 実装}

ヒューマノイドロボット HRP-2 に提案操作システム を実装した。本システムは自然言語指令の音声認識エン ジンとして上記 NEC 社が開発した「音声認識モジュー ル」(Speech Recognition Module)[8]を使用した. 音声 認識モジュールを組み込んだヒューマノイドロボット HRP-2 の頭部を Fig.3 に示す。ソフトウェアシステム の概要をFig.2 に示す。音声認識モジュールは RT ミ ドルウエア (Speech Recognition RT Component) とし て実装された。構築システムの他のコンポーネントは、 Speech Recognition RT Component からの音声認識結 果 (XML 形式) を解析して、行動・行為辞書に基づいて、 行動コマンドに変換する「Command RT Component」, ヒューマノイドロボット HRP-2の頭部に搭載された視 覚センサを用いて，知覚行為を実行する対象物体の位 置・姿勢を VVVシステム[9]により認識する「Visual Perception Module」, 行動レベルのコマンドに基づい て行動を生成する「Behavior Module」，ヒューマノイ ドロボットの全身動作を生成する「Motion Generation Module」より構成される。



Fig.2 System Overview

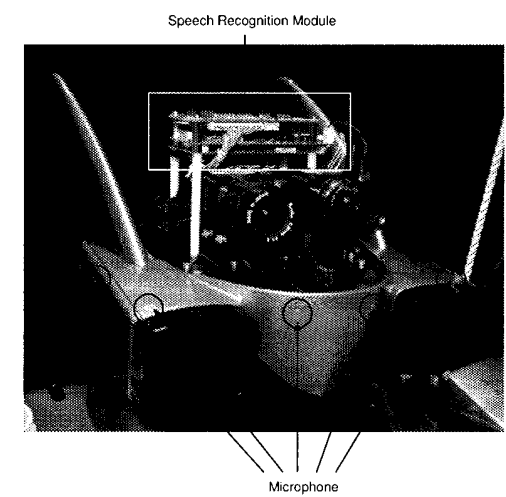

Fig.3 The Newly Developed Speech Recognition Module and five of the 8ch Microphone Array Mounted on HRP-2 Head

\section{5. おわりに}

本研究では, 自然言語を用いて柔軟にヒューマノイ ドロボットを操作できるシステムの開発にについて報 告した。日常生活環境で人間の支援を行うために多種 多様な夕スクに共通に必要とされる基本行動・行為辞 書の構築および、ヒューマノイドロボット HRP - 2 に 実装したシステムについて述べた。

\section{参考文献}

[1] N. Nilsson: "A Mobile Automaton: an Application of Artificial Intelligence Techniques, " In Proc. of the First International Joint Conference on Artificial Intelligence, pp.509-520, 1969.

[2] 稲邑哲也，園四朋之，川路友博，稲葉雅幸：”確率的空間 記憶モデルに基づく人間ロボット間の協調的タスク遂行 システム”, 第 20 回人工知能学会全国大会論文予稿集, p.3F3-1, 2006 .

[3] 松井俊浩、麻生英樹、John Fry 他: “オフィス移動ロボッ 卜Jijo-2 の音声対話システム”、日本ロボット学会誌、 第 18 炎、 2 号、 2000.

[4] 田中穂積: “言語理解と行動制御”, 平成 13 年度 平成 17 年度科学研究費補助金 (学術創成研究) 研究成果報告 書、2006.

[5] 䋲澤正犬，樏原靖，白井良明，島⿴伸敬，三浦純，"サ一 ビスロボットのための対話システム”，システム制御情報 学会論文誌, Vol. 16, No. 4, pp. 174-182, Apr. 2003.

[6] Norman I. Badler, Rama Bindiganavale, Jan Allbeck, William Schuler, Liwei Zhao, Seung-Joo Lee, Hogeun Shin, and Martha Palmer: "Parameterized Action Representation and Natural Language Instructions for Dynamic Behavior Modification of Embodied Agents", AAAI Spring Symposium 2000.

[7] Deb Roby: "Semiotic schemas: a framework for grounding language in action and perception", Artificial Intelligence, Volume 167, Issue 1-2, 2005.

[8] 高野、宇田、石田、西沢、藤田: “ロボットプラットフォー ム RoboStudioによるRT コンポーネントの実現”、ロ ボティクス・メカトロニクス講演会 2007 講演予稿集、 2007.

[9] Y. Sumi, Y. Kawai, T. Yoshimi, and F. Tomita: "3D Object Recognition in Cluttered Environments by Segment-Based Stereo Vision," Int. J. Computer Vision, Vol.46, No.1, pp. 5-23, 2002. 